\title{
Disciplinary Measures in Nigerian Senior Secondary Schools: Issues and Prospects
}

\author{
${ }^{1}$ Ajibola A. Lukman $\&{ }^{2}$ Ali A. Hamadi \\ ${ }^{1,2}$ College Of Education, P.M.B 1021, Zing, Taraba State, Nigeria.
}

\begin{abstract}
This paper analytically discusses the disciplinary measures used in senior secondary schools in Nigeria with the emphasis on the problems encountered with a view to proffering far reaching solutions to the challenges. The paper posits that the causes and kinds of disciplinary problems experienced are determinant of disciplinary measures to be taken. To this end, truancy, absenteeism, fighting, stealing and drug addiction among others are typical examples of disciplinary problems experienced in Nigerian secondary schools. While parental/home, political, social and economic, school environment, school curriculum and peer group influence among others are the causes of disciplinary problems. The study asserts that discipline is not necessarily punishment but punishment is one of the disciplinary measures in school. Finally, the paper recommends moral punishment and well spelt out code of conduct for all students to follow.
\end{abstract}

Keywords: Disciplinary Measures, Issues and Prospects, Secondary School

\section{Introduction}

Discipline is probably the most difficult and unpleasant part of teaching profession. The teacher is faced with the challenges of educating, socializing, empowering and certifying students, but with the help of good teaching atmosphere (Fafunwa, 2004; Farrant, 2004).

Students' misbehaviour is a prevailing problem affecting schools not only in Nigeria but also across the many nations around the world. Students' misconduct in the classroom interferes with teaching and learning and is thought to be precursor to later school dropout and similar negative social outcomes.

The indiscipline problem in schools is ranked as a major problem among students of secondary schools in Nigeria. Disruptive behaviour is a concern to schools and parents and to fellow students, whose education may be adversely affected. So it cannot be ignored, and schools must tailor a well-understood sound behaviour and discipline policy. When schools effectively communicate rules, set high expectations and provided frequent feedback, the need for discipline will likely be infrequent.

However, action is occasionally required to correct a situation where a student has broken the rules or is not putting in the required amount of effort. The approach taken to the disciplinary action often determines its effectiveness. Many traditional approaches to discipline are negative, punitive and reactive, which result in bad feelings for all parties involved. A positive approach to discipline involves a process designed to solve performance problems and encourage good performance. The basic theory behind the positive discipline approach is that when a student is treated as an adult who must solve a problem, rather than as a child who must be punished, the student is more likely to respond positively and correct the problem.

Well before any disciplinary action is required, there must be acceptance and understanding of the rules of conduct and the disciplinary system by both teachers and students. Students should know exactly what is expected of them and what the consequences will be if they do not meet those expectations. The rules should be consistent and fair. The discipline system will be more effective when the disciplinary action is meant to tackle the root cause of indiscipline behaviour of the students. It is against this backdrop, the study digs into the issues surrounding disciplinary measures and its prospects in Nigerian secondary schools.

\section{Conceptual Framework: Discipline in School System}

Discipline globally viewed could be termed to mean training that enables an individual to develop an orderly conduct and self-control as well as self-direction (Egwunyenga, 2000). Therefore, discipline defines the limitations of an individual or a group of people. It is the practice of restraint, which may be self-imposed. With reference to the school, Adesina (1980) described it as a situation whereby students are taught to respect the school authorities, to observe the school laws and regulations and to maintain established standard of behaviour. This means that respect for self and respect for others are involved (Peretomode, 1998).

School discipline is an essential element in school administration. This is because discipline is a mode of life in accordance with laid down rules of the society to which all members must conform, and the violation of which are questionable and also disciplined. It is seen as a process of training and learning that fosters growth and development (Imaguezor, 1997). The aim of discipline is therefore, to help the individual to be well adjusted, happy and useful to his society. The doctrine of school discipline according to Nolte (1980) and 
Barrell (1978) is based on the concept of "loco parentis" which allows school authorities full responsibility for children's upbringing, the right of discipline and control. In effect, teachers have the right to punish students who contravene school laws.Discipline refers to a systematic instruction given to a disciple or a student. To discipline means to instruct a person to follow a particular code of conduct.

In a nutshell, school discipline refers to regulation of children and the maintenance of order ("rules") in schools. These rules may, for example, define the expected standards of clothing, timekeeping, social behaviour and work ethics. The term may be applied to the punishment which is the consequence of transgression of the code of behaviour. In other words, the usage of school discipline sometimes means upholding disciplinary action against nonconformity with the school rules.

\section{Issues in Disciplinary Measures}

School is an institution with a specific purpose, to nurture the youngster in such a way that he will be useful to himself and society. Most of themisbehaviours of students in Nigerian secondary schools result from a complexity of factors that reside both within the child and forces outside him. This could be examined under common disciplinary problems and severe disciplinary problems.

\section{Common Disciplinary Problems}

Rosen (1997) distinguishes the following ten types of disciplinary problems which may lead to a learner's suspension, namely; defiance of school authority; not reporting to after-school detention or Saturday school; class disruption; truancy; fighting; the use of profanity; damaging school property; dress code violations; theft; and leaving campus without permission.

The other common types of disciplinary problems experienced in secondary schools as mentioned by Donnelly (2000) include fights, insubordination, little support for educators, a general climate of disrespect, and distrust of the administration. Emphasizing that the types of disciplinary problems mentioned above are the ones being experienced in Nigerian secondary schools.

McManus (1995) lists several types of misbehaviour which make the work of educators difficult. These include; repeatedly asking to go to the toilet; missing lessons, absconding; smoking in the toilets; pushing past the educator; playing with matches in class; making rude remarks to the educator; talking when the learner is supposed to be writing; being abusive to the educator; fighting in class; chasing one another around the classroom; packing up early, as if to leave; taking the educator's property; wearing bizarre clothing and makeup; threatening the educator; leaving class early; and commenting on the work.

\section{Severe Disciplinary Problems}

Alidzulwi (2000) attested to the fact that severe disciplinary problems have been experienced in secondary schools, stressing that some schools have developed into battlefields, since learners carry weapons such as guns to schools. Incidences have been reported of learners stabbing their educators and principals with pangas, and they also fight each other.

A survey on educators' opinions on violence in education conducted by Frazier and others (in: Smith 1999) reveals serious cases of learner violence. These include the burning down of classrooms, learners attacking educators and principals, learners setting fire to educators' cars, and attacking taxi drivers, in order to steal their cars.

Moodj (in: Smith 1999) distinguishes the kinds of perpetrators of school violence as those making themselves guilty of

- Verbal violence (name-calling, creating disorder, bullying);

- More serious behaviour, including vandalism, theft, blackmail;

- Extortions, or using a weapon on the school premises;

- Planned violence, which includes physical violence with weapons in or outside the school; and

- The sexual harassment of girls.

\section{Causes of Disciplinary Problems}

At this juncture, there is every reason to know the causes of these ugly actions and reactions in our institute of learning. In Nigeria for instance, the ills and vices that go on in the society have their effects in schools. Students, teachers and even school managers are involved in one form of indiscipline or the other. Generally speaking, some of the causes are;

\section{Parental/Home Factor}

Most authors regard parents as of the greatest importance in creating a conducive teaching and learning atmosphere. It seems that the lack of parental involvement is the major cause of disciplinary problems in secondary schools. Alidzulwi (2000), points out that many parents are not involved in the education of their 
children, causing poor results, high dropout rates, and the absence of discipline in schools. Bowman (2004) is of the opinion that parents' failure to teach their children discipline is identified as the greatest contributing factor to disciplinary problems in schools. Louw and Barnes (2003) affirmed that they have never seen a problem child, only problem parents. In his study, Varma (1993) also points out that those learners who behave badly at school do not receive proper discipline at home.

When analyzing the inability of parents to take care of their children on all socio-economic levels and in all racial groups, Rossouw (2003) regards the decline in discipline in most schools as originating from the communities rather than from schools. Stressing that parents show a lack of tolerance and respect towards government authorities as well as towards educators, and some have a laissez-faire approach towards their children.

Some other factors related to the lack of parental involvement in schools that influence discipline are, single parent homes; a lack of parental control at home; the negative influence of television; neighbourhood and community problems that influence the home; and values differences between the home and the school.

\section{Political, Social and Economic Factors}

Rossouw (2003) claims that educators have reported that they are uncertain, confused and afraid of infringing upon learners' rights, and of being accused of misconduct.Saying that the over-emphasis placed on learners' rights may cause a "don't-care attitude" and a lack of regard for the educators' role in the classroom. This may cause some learners not to strive to excel. Instead, they try to influence their classmates negatively to exhibit the same lack of discipline.

Children who experience social alienation from others are often misbehaved.

According to Lewis (1991), this situation arises within most families where children feel rejected. This finding (the significant relationship between isolation and poor behavior) is supported by Butchart in 1998 when he indicates that emotional disconnection from family, friends, and peers results in feelings of isolation and alienation for the child. According to Butchart (1998), "These feelings experienced by the child may ultimately develop into what is referred to as 'psychological pains', which may cause problems such as physical assault, gang violence, substance abuse, and many others".

The political situation in Nigeria is also blamed for children's misbehavior. Moloi (in: Rossouw 2003) states that the involvement of the youth in the political stability and national elections in 1999 caused them to develop arrogance towards adults, that is, both educators and parents". Accordingly, Maree (in: Rossouw 2003) also blames the political situation of the nineties in Nigeria where the causes of violence in schools were politically motivated.

\section{School Environment}

Every school manager is committed to ensuring that school provides a safe and orderly environment in which teaching and learning take place each day. Bazemore (1997) posits that safe and supportive school environments depend on students, staff and parents demonstrating mutual respect. In other words, all members of the school community students, staff and parents must know and understand the standards of behaviour which all students are expected to live up to and the consequences if these standards are not met.

Every student has the right to a learning environment free from bullying and intimidation and to feel safe and happy at school. They have a right to be treated fairly and with dignity (Terry, 2001). In addition, every community has rules. The school community is no exception. A school makes reasonable rules for the good order of the school and the discipline of students. Schools have the power to enforce these rules by using discipline or punishment. According to Rowne (2005),

"The school priorities are designed to ensure that all students are provided with a harmonious environment where they can learn and thrive. Therefore, good discipline in a school is required to ensure that school is able to provide quality education for all students and to guarantee the care and safety of the school community. A harmonious work environment at school increases the chance of students realizing their full educational potential".

However, a lawless community raises unproductive members for the society. In the same vein, a lawless school environment promotes disciplinary challenges to the school manager and teachers. Students in such school disrespect their fellow students, teachers and community members and engage in protest which promulgates violence, discrimination, harassment, bullying and intimidation, using of weapons, drugs, alcohol and tobacco (Mitchell, 1996).

\section{The Curriculum}

The relevance of the curriculum to learners' needs also influences discipline at school. In research done by Raven (in: Besag 1991), it was ascertained that learners engage in several forms of deviant behaviour if the curriculum is not able to offer them opportunities for self-development and a sense of personal worth, and do 
not address the aims that are promoted by society. Besag (1991) further maintains that learners resort to taking matters into their own hands if they believe that the curriculum is irrelevant and boring. Accordingly Doveton (1991) indicates that deviant behaviour is always experienced if the curriculum that is offered to learners is irrelevant to their interests and the needs of their communities.

\section{Peer Group Influence}

The peer group influences what the child values, knows, wears, eats and learns. The extent of this influence however depends on other situational constraints, such as the age and personality of children and the nature of the group (Harris, 1998; Hartup, 1983).

There is no doubt that considerable evidence supports the statement that peer relationships influence the growth of problem behaviour in youth. The peer group can demand blind obedience to a group norm, which can result in socially alienated gangs with pathological outlooks (Perry, 1987). Douge (1993) indicated that poor peer relationships were closely associated with social cognitive skill deficits.

According to Seita, Mitchell and Tobin (1996) "When the family has been unable to fully meet a child's needs, other adults who play a significant role in the child's life have extraordinary potential for influencing the child in taking charge of his or her life". It is worth noting that peer influence can lead to discipline problems and delinquent behaviours both inside and outside school. It is also clear that one of the major ways that deviant youths become even more deviant is through unrestricted interaction with deviant peers. Hartung (1965) posited that criminality is socio-culturally learned in the process of interacting with family members and peers in small intimate groups. This process includes learning the techniques to commit delinquent acts and developing the rationalizations to protect one's self-concept.

\section{Theoretical Framework: Disciplinary Measures in Secondary Schools}

Disciplinary measuresin secondary schools being the central focus of this study, it is important to note that disciplinary action must commensurate with offence committed. Geiger (2000) regarded a lack of discipline as a chronic problem in the classroom, and the manner in which it is being handled as determining the amount of learning that is taking place in schools. While Fuentes (2003) indicated that every year more than three million students are suspended and nearly 100000 more are expelled from primary up to university in the United States of America. Many learners face police action for disciplinary measure that merit offence committed.

However, students' indiscipline seems to be ubiquitous in the $21^{\text {st }}$ century in secondary schools in Nigeria. With recent problem increase in school enrolment, discipline problems are bound to accentuate and cause more burdens on teachers and school administration. According to Rigby (2000) "students' indiscipline has plagued schools leading to series of unrest particularly in secondary school". Consequentlydisciplinary measures taken must go along with the gravity of their offences. Disciplinary measures in the $21^{\text {st }}$ century could be discussedunder historical and contemporary methods as follows:-

Historical Method; Throughout the history of education, corporal punishment was regarded as a means of maintaining discipline in the school. Vornberg (2002) contends that in practice corporal punishment means that students are punished with the birch, cane, paddle or strap if they did something wrong. Maree (in Egwuonu 2008) added that the proponents of corporal punishment justify its administration on various grounds, indicating how it is capable of building character, contributing to the rapid reduction or elimination of unwanted behavioural patterns, and facilitating learning, whilst at the same time teaching respect for rules and authority.

However, stakeholders in education have condemned corporal punishment on the basis that is out of all proportion. McManus (1995) opined that when punishment is out of all proportion to the mistake, it breeds antagonisms to the school. Stressing the fact that the child becomes more hostile, this leads to a large number of psychological and physiological troubles. Grunwald (1998) argued that if education means the act of leading out, the act of unfolding, the act of developing then corporal punishment could never be educative. Concluding that it will not enable the child to adjust himself to the environment, the child may become indiscipline and quarrelsome and may become antisocial.

Modern Method; The National Policy on Education (2004) urges educators to use discipline rather than punishment proactively and constructively. It is expected that the learners experience an educative, corrective approach where they will learn to exercise self-control, to respect others, and to accept the consequences of their actions. However, there is a feeling that school discipline practices are generally informed by theory from psychologists and educators. Bell (1995) identified the following theories to form a comprehensive discipline strategy for an entire school or particular class:-

i. Positive Approach: This approach is grounded in teachers' respect for learners. It instills in learners a sense of responsibility by using youth/adult partnerships to develop and share clear rules, provide daily opportunities for success and administer in-school suspension for noncompliant pupils. 
ii. Teacher Effectiveness Training: This method differentiates between teacher-owned and pupil-owned problems, and proposes different strategies for dealing with each. Emmer (2005) opined that effective teacher training reflects in pupils knowledge through problem-solving and negotiation techniques.

iii. Appropriate School Leaving Theory and Educational Philosophy: It is a strategy for preventing violence and promoting order and discipline in schools, put forward by educational philosopher Greenberg (1987) and practiced by some schools. Positive school culture and climate will to a large extent aid reduction of indiscipline in school.

iv. Detention: This requires the pupils to remain school at a given time of the school day (such as lunch, recess or after school) or even to attend school on a non-school day, e.g. "Saturday detention" held at some US and UK schools. In the UK, the Education Act 1997 obliges a school to give parents at least 24 hours notice of a detention outside school hours. This is not common in Nigerian schools but in specialized schools like "Command Secondary Schools or Navy Secondary Schools" such practice is common perhaps because of the military nature of the schools.

v. Suspension or Temporary Exclusion: This is mandatory leave assigned to a student as a form of punishment that can last anywhere from one day to several weeks, during which time the pupils cannot attend regular lessons. The student's parents/guardians are notified of the reason for and duration of the out-of-school suspension. Pettit (1997) contends that sometimes pupils have to complete work during their suspensions for which they receive no credit. Stressing that students only report in school but serve punishment like cutting grass or digging holes or uprooting a plant or work in school farm.

vi. Exclusion or Expulsion: Withdrawing or permanent exclusion is the removal of a pupil permanently from the school. This is the ultimate last resort, when all other methods of discipline have failed. However, in extreme situations, it may also be used for a single offense. For in Nigerian schools, school head can only suspend a pupil while exclusion or expulsion of pupil from school is the right of the Ministry of Education based on the school had report. However, expulsion from a private school is a more straightforward matter, since the school can merely terminate its contract with the parents.

vii. Deprivation of Privilege: It is useful and efficient form of punishment. Dodge (1993) affirmed that loss of position, prohibition from playing any game in the school compound for a certain period could go a long way in improving the wrong doer.

viii. Moral Punishment: Moral punishment such as apologies, public or private degrading from positions etc is sometimes resorted to. Widman (1987) contended that great care and discernment are needed before such form of punishment is resorted to because it could never halt self-respect of the wrong doer.

ix. Self-government: It means the organization of community life of the school in such a manner that responsibility for managing the school and running it in certain activities is shared with the pupils. It therefore, enables the pupils to learn in a practical way the principles of citizenship, co-operate living and democratic organization.

x. Praise and Blame: The teacher must be very careful in his allocation of praise and blame. Tongue is said to be most powerful weapon in the teacher's armory and its use may vary from a mild reproof to the bitterest sarcasm and vulgar abuse. Wasmund (1965) described sarcasm as a weapon which is sometimes resorted to by the teacher, which creates a conflict between the teacher and the student easily. Stressing that sarcasm lower the self-respect of the pupil, tampers with his or her ego and permanently estrange him from the teacher and the school order.

xi. Rewards: There is a belief that reward is not only right and desirable but also indispensable. Rewards can be given for attendance, conduct, progress, games, badges and certificates may be given as rewards. Group rewards might be given, for pupils will become socio-centric not egocentric. Teamwork can be fostered and wholesome all school spirit can be secured.

xii. Punishment: It has a necessary place in the school economy but it must be based on certain principles if it is not to be a "hit or miss" affair. Seita (1996) identified the following guidelines for the use of punishment:-

- Punishment should fit the "crime" as well as the "criminal". This is because individuals differ from one another in the basic temperamental patterns which they inherit, and in those which they subsequently develop. For example, some children are extremely self-assertive, others unduly submissive. Some are very easily provoked to anger, others relatively placid and others patient while some are by nature very sociable and others solitary in their outlook. Therefore, one needs to exercise care in making any general statement regarding the effectiveness or otherwise upon children of any form of correctives.

- There should be no uncertainty about the punishment. The element of uncertainty in punishment renders it almost inoperative and postponement is almost fatal.

- $\quad$ Punishment should help the offender to improve and this condition is satisfied only when he realized his mistake, feels regret or shame for his conduct and makes up his mind not to commit the offence again. When the offender realized that he deserves punishment, punishment becomes necessary. 
- $\quad$ Punishment should be inflicted to the barest possible minimum. Familiarity breeds not so much contempt, as indifferences in such matters.

In a nutshell, all the above-mentioned measures except blame and sarcasm are positive disciplinary measures to secure but the instinctive and impulsive reactions of children themselves may lead to evil, if not properly directed. So proper guidance of youthful zeal has both negative and positive aspects.Scult (2009) opined that children are dynamic, effervescent and therefore, heedless. They need checks to prevent excesses, restrictions to keep them within the speed limit of property. In lieu of this, Rogers (1995) came up with a school discipline policy which provides a framework that corresponds with what a school will seek to practice. The framework aims at achieving the following; establish a stable social learning environment;encourage students to be responsible for their own behaviour, to develop self-discipline, and enhance their self-worth, and to respect the rights and feelings of others, such as their fellow students and teachers; set out the school's expectations and rights, and to enhance positive behaviour; and establish a set of preferred practices and due processes, whereby the staff may address unacceptable student behaviour.

\section{Criteria ForAn Effective Disciplinary Measures}

For the school system to achieve its desired goals, disciplinary measures must be properly enforced. Again, if discipline is to be effective, it should;

- Emphasize correcting the problem rather than distributing punishment.

- Maintain the students' self-esteem and dignity.

- Provide for increasingly serious consequences if the problem is not resolved.

- Be easy for teacher to administer and evaluate.

- Result in the desired behavioural change in the student.

\section{Key Components Of An Effective Disciplinary System}

1. Mutual respect between the teacher and the students should be maintained.

2. Maintain or enhance motivation if possible.

3. Hold a coaching/counselling meeting as soon as possible when the problem is first identified.

4. Always hold the meeting in private. If disciplinary action is taken in front of others, the students are likely to become defensive and less open.

5. During the disciplinary meeting;

- Review the facts and state the problem in terms of desired performance and actual performance.

- Give the student a chance to explain or ask why the problem is occurring.

- Listen to what the student has to say.

- Explain the relational for the policy or rule that was violated.

- Ask the student for possible solutions to the problem.

- Clearly communicate the changes that needed to be made and the time frame to making them.

- Express confidence in the students' ability to change/improve. End on a positive note.

6. Keep the discussion confidential.

7. Follow-up as required and provide regular feedback.

8. Take additional disciplinary action if necessary.

\section{Recommendations}

i. School management should approach the problem of discipline with empathy for the possible problems the learners may be experiencing at home or at school that cause their poor behavior. This necessitates the services of a guidance and counsellor in all schools.

ii. Since parents have been cited as influential in the development of disciplinary problems in learners, it is also of vital importance to look into how parent involvement in the education of their children may be improved. Parents have a major role to play in ensuring that proper teaching and learning are attainable in our schools. Therefore, the parents, school management, and other staffers of the school should join hands in ensuring that a climate conducive to teaching and learning is prevalent in the schools.

iii. Moral punishment, rewards, praise and blame create room for reinforcement of positive performance which is the guideline for the impulsiveness of the students.

iv. Parents should make education a priority for their children, this will make the children achieve better and behave in an acceptable manner.

v. Moderate right syndrome and formulation of behavioural expectations forteachers and learners will improve school discipline. In view of the above, a Code of Conduct for learners and staff is very important in all schools.It serves as an important stepping-stone towards fostering a culture of learning mutual respect, accountability, tolerance, co-operation, personal development within the school and its surroundings. 


\section{Conclusion}

Having discussed the key components of effective disciplinary measures, it is equally important to emphasize the need for school rules and regulations. According to Duke \& Canady, (1991) successful schools have high expectations of discipline, and promote good relationships between children and staff. They identified the following as rationale for rules and regulations; to maintain law and order within the school; to keep decorum in the school and its environs; to reduce crime within and outside the school; to enable individual to be well-cultured and well-controlled; individual attitudes are channelled towards well perspective; and guide to development of school rules and regulations.

\section{References}

[1]. Adesina, S.(1980) Introduction to Educational Planning. Ile-Ife: University of IfePress

[2]. Alidzulwi, T. A. (2000). The role of parents in values education with special references to the situation in Venda (Northern Province). Unpublished Med dissertation. Stellenbosch: University of Stellenbosch.

[3]. Barrel, G. R. (1978).Teachers and the Law.Great Britain:Methuen and Co. Ltd.

[4]. Bazemore, J. (1997). Legislation on school governors' power to appoint educators: friend or foe. South African Journal of Education, 29(2):171-184.

[5]. Besag, E.B. (1991). Bullies and victims in schools. Milton Keynes: Open University Press.

[6]. Bowman, D. H. (2004). Report notes on the impact of student behaviour. Education Week, 23(37):3.

[7]. Butchart, R. E. (1998).Classroom discipline in American schools.New York: State University of New York Press.Dodge, N. (1993). Active supervision: An intervention to reduce high school tardiness. Education and Treatment of Children, 31(1):39-54.

[8]. Douge, A. (1993). Beyond Discipline World Prosperity.Alexandria, Va: ASCD.

[9]. Donnelly, J. (2000).Two simple rules-discipline problems down.Pro Principal,16 (7):1-3.

[10]. Doveton, E. (1991).Managerial activities of the teacher. Island: Lexicon Publishers Duke, D. L. and R. L. Canady (1991).School Policy. New York: McGraw-HillInc

[11]. Emmer, L. K. (2005) Teacher attitudes about classroom conditions.Journal of Educational Administration, 47(3):323-336.

[12]. Egwunyenga, E. J. 2000 Essentials of School Administration. Benin City; Justice Jeco Publishers

[13]. Fafunwa, A. B. (2004). History of Education in Nigeria. Ibadan: NPS Educational Publishers

[14]. Farrant, J. S. (2004). Principles and Practice of Education. Edinburgh: London Group Ltd.

[15]. Frazier, H. C. 1999 Corporal and Capital Punishment of Juveniles, journal of Medical Law. 93, 996-1004

[16]. Fuentes, A. (2003).Discipline and punishment.Nation, 277(200):17-20

[17]. Geiger, B. (2000) Discipline through 8 grade classrooms. Education, 121(2):383.

[18]. Greenberg, A. P. (1987).Student aggression. New York: The Guilford Press Grunwald, H. (1998). "Maintaining Effective Classroom Control and

[19]. Discipline" in S.B. Nwideeduh, (ed). Focus on Effective Teaching in Schools. PortHarcourt: Para graphics Harris, A. (2002). The New School Leader for the $21^{\text {st }}$ Century. Oxford: ScarecrowPress.

[20]. Hartung, M. (1965). Teachers' commitment focuses: a three-dimensional view.

[21]. The Journal of Management Development, 28(5):425-440.

[22]. Hartup, E. (1983). Perceptions of discipline and ensuing discipline problems in secondary education. The South African Journal of Education, 20(1):34-41.

[23]. Imaguezer, J. (1997). The role of educators in the management of school discipline in the Nkangala Region of Mpumalanga. Unpublished MEd dissertation. Pretoria: University of South Africa.

[24]. Lewis, R. (1991). The discipline dilemma.Hawthorn: Australian Council for Educational Research LTD.

[25]. Louw, E \& Barnes, M. (2003)Stout kind: dis die ouers se skuld. Die Huisgenoot.

[26]. McManus, M. (1995).Troublesome behaviour in the classroom. London: Routledge.

[27]. Moloi, O. C. (2003). Student discipline strategies. Albany: State University of New York Press.

[28]. Moodj, E. D. (1999). "Tuck in that shirt". Race, class, gender and discipline in an urban school. Sociological Perspectives, 48 (1):25-48.

[29]. Nolte, M. (1980). The impact of the abolition of corporal punishment on teacher morale: 1994-2004. South African Journal of Education, 27(2):283-300.

[30]. National Policy on Education (2004), Lagos: NERDC Press Peretomode, V. F. 1998 Introduction to educational planning and supervision. Lagos:Joja Educational Research and Publishers Ltd

[31]. Perry, C. (1987). The impact of leadership and management on the construction of professional identity in school learning mentors. Educational Studies, 32(2):157-169

[32]. Pettit, A. (1997). Why do they stay? Elementary teachers' perceptions of job satisfaction and retention. Professional Educator, 32(2):1-18.

[33]. Rosen, L. (1997). School discipline, best practices for administrators. Thousand Oaks: Corwin Press.

[34]. Rowne, D. E. (2005). Teacher perceptions of levels of professional contribution to the school. College Student Journal, 43(3):852859 ,

[35]. Rigby k (2000). Bullying in Schools and what to do about it? London: Jessica Kingsley

[36]. Rossouw.J.P. (2003).Learner discipline in South African public schools. Koers.

[37]. Scult, J.A. (2009). Positive behavioural supports for the classroom.Upper SaddleRiver, New Jersey: Pearson Prentice Hall.

[38]. Seita, M, Mitchell, R \& Tobin, C.(1996). Rethinking Student Discipline. ThousandOaks: Corwin Press.

[39]. Terry, B. W. (2001). Conducting Educational Research.Florida: Harcourt Brace \& Company.

[40]. Varma, PV. (1993). The Management of behavior in schools.New York: Longman Publishing

[41]. Wasmund, E. (1965). Antisocial behavior in schools: Strategies and best practices.Belmont: Brooks/Cole Publishing Company.

[42]. Widman, J. H. (1987). Instructor attitudes toward students: job satisfaction and student outcomes.College Teaching, 56(4):225-230. 